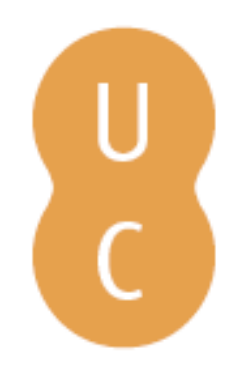

\title{
nommalina
}

\section{Experimental study on fire behaviour and soil combustion in the high altitude tropical grasslands}

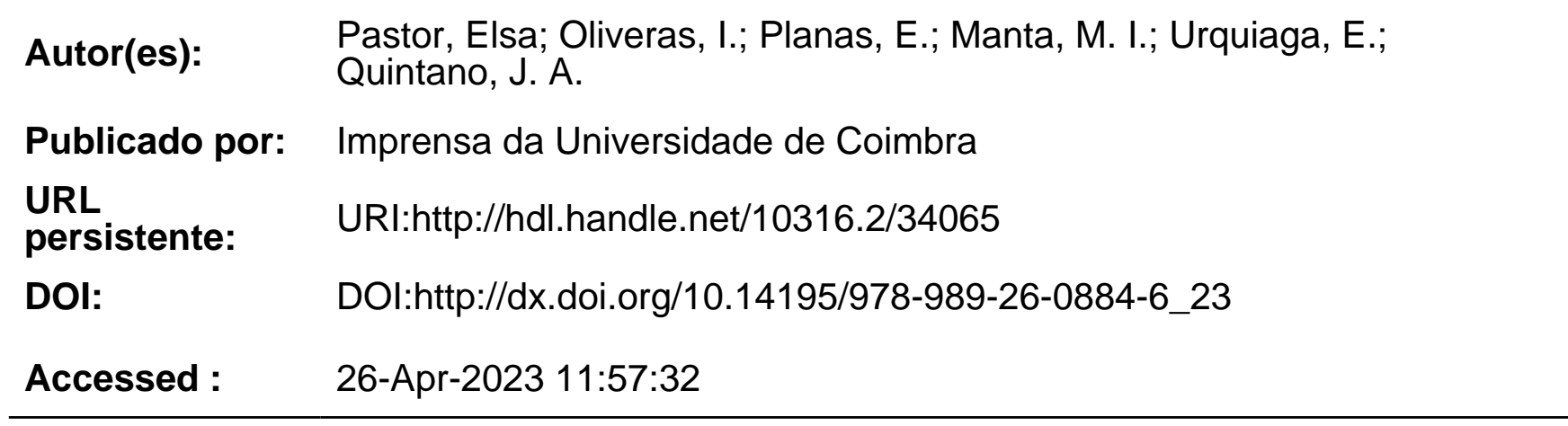

A navegação consulta e descarregamento dos títulos inseridos nas Bibliotecas Digitais UC Digitalis, UC Pombalina e UC Impactum, pressupõem a aceitação plena e sem reservas dos Termos e Condições de Uso destas Bibliotecas Digitais, disponíveis em https://digitalis.uc.pt/pt-pt/termos.

Conforme exposto nos referidos Termos e Condições de Uso, o descarregamento de títulos de acesso restrito requer uma licença válida de autorização devendo o utilizador aceder ao(s) documento(s) a partir de um endereço de IP da instituição detentora da supramencionada licença.

Ao utilizador é apenas permitido o descarregamento para uso pessoal, pelo que o emprego do(s) título(s) descarregado(s) para outro fim, designadamente comercial, carece de autorização do respetivo autor ou editor da obra.

Na medida em que todas as obras da UC Digitalis se encontram protegidas pelo Código do Direito de Autor e Direitos Conexos e demais legislação aplicável, toda a cópia, parcial ou total, deste documento, nos casos em que é legalmente admitida, deverá conter ou fazer-se acompanhar por este aviso.

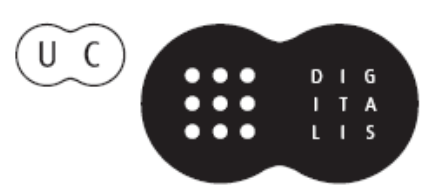




\section{ADVANCES IN}

Forest Fire

\section{RESEARCH}

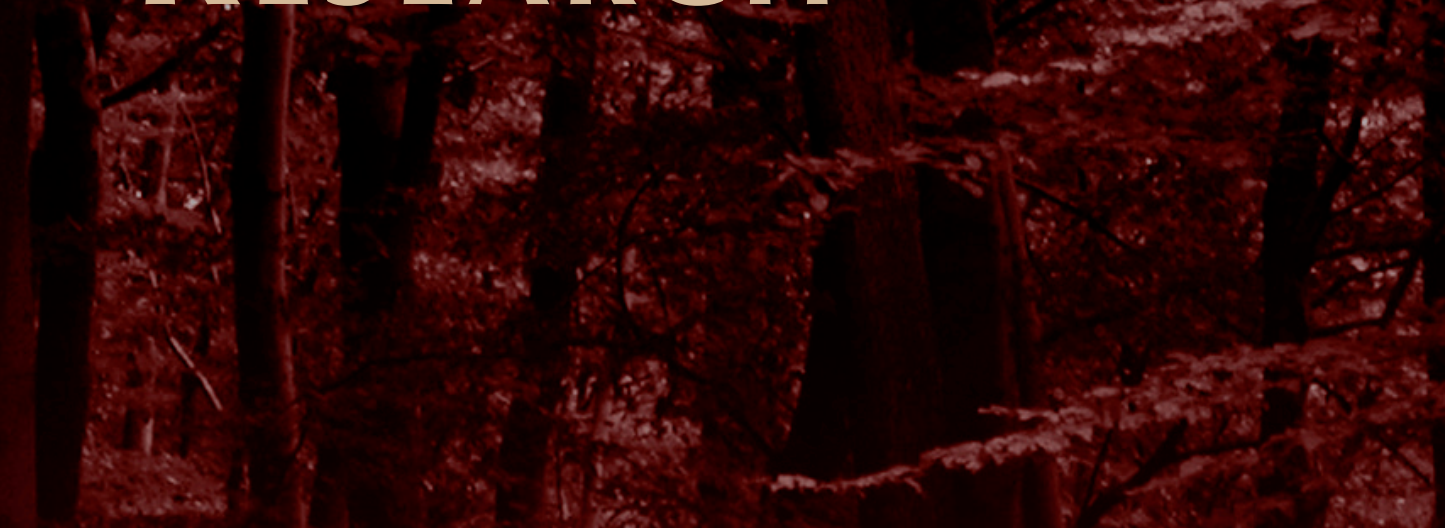

\section{DOMINGOS XAVIER VIEGAS}

\section{EDITOR}




\title{
Experimental study on fire behaviour and soil combustion in the high altitude tropical grasslands
}

\author{
Elsa Pastor ${ }^{\mathrm{a}}$, I. Oliveras ${ }^{\mathrm{b}, \mathrm{c}}$, E. Planas $^{\mathrm{a}}$, M.I. Manta ${ }^{\mathrm{d}}$, E. Urquiaga ${ }^{\mathrm{e}}$, J.A. Quintano $^{\mathrm{e}}$ \\ ${ }^{a}$ Department of Chemical Engineering, Centre for Technological Risk Studies, Universitat \\ Politècnica de Catalunya-BarcelonaTech, Diagonal 647, E-08028 Barcelona, Catalonia, Spain. \\ elsa.pastor@upc.edu, eulalia.planas@upc.edu \\ ${ }^{b}$ Environmental Change Institute, School of Geography and the Environment, University of Oxford, \\ South Parks Road OX13QY Oxford, UK. imma.oliveras@ouce.ox.ac.uk \\ ${ }^{c}$ Nature Conservation and Plant Ecology Group, Wageningen University, Building 100, \\ Droevendaalsesteg $3^{a}$, 6708PB Wageningen, Netherlands. \\ ${ }^{d}$ Department of Forest Management, Universidad Nacional Agraria La Molina, Av. de la \\ universidad s/n. Apartado 12-056. Lima 12, Perú.mmanta@lamolina.edu.pe \\ ${ }^{e}$ Departamento de Botánica, Universidad de San Antonio Abad del Cusco, Av. Cultura 733, Cusco, \\ Perú.eurquiaga@gmail.com,biojoanqlcp@gmail.com
}

\begin{abstract}
Tropical mountain cloud forests (TMCFs) are becoming new fire-prone areas in the Neotropics due to ongoing climate change. TMCFs are increasingly suffering from drought episodes during which fires starting at the puna grasslands that occur immediately above the forest, tend to penetrate into the TMCFs causing irreversible damage. Moreover, when the fire reaches the puna-forest treeline it frequently exhibits smouldering propagation consuming the humic soil layer resulting in large carbon emissions.

This paper presents an experimental program set up to study critical conditions that favour fire spread in the puna-TMCFs interface. The objective is twofold: to provide understanding of the threshold environment and fuel conditions allowing sustainable back-fire propagation in puna grasslands when advancing towards the TMCFs and to investigate the onset of smouldering combustion of the humic layers of the puna soil near the TMCFs treeline.

The study area was located at tropical Andean puna grasslands at the Cusco region (Southern Peru, bordering Manu National Park). It involved two different locations, one for the ground fire experiments and the other for the grassfire sustainability and behaviour tests. The first site comprised 20 paired ground plots $(0.5 \mathrm{~m} \mathrm{x} 0.5 \mathrm{~m})$ which were ignited by a purpose-standardized ignition procedure and monitored by thermocouples during $48 \mathrm{~h}$. The second site was divided in 12 grassland plots $(20 \mathrm{~m}$ x $5 \mathrm{~m})$ of two different fuel ages. Each grassfire was recorded with video and infrared cameras and witnessed by ground observers to detect fine scale changes in fire activity due to fuel and wind variability. Environmental conditions were constantly monitored in both type of experiments.

The ground tests provide novel information about smouldering fires in a real environment, going beyond classic laboratory experimentation. Soil temperatures higher than $100^{\circ} \mathrm{C}$ were observed to last for around 20 hours with maximum temperatures around $450{ }^{\circ} \mathrm{C}$. The surface fires experiments revealed dead fuel load and fuel moisture content thresholds $\left(0.2 \mathrm{~kg} \mathrm{~m}^{-2}\right.$ and $20 \%$ respectively) that would explain back-fire sustainability, reaching those go-fires pseudo-stationary rates of spread of around 0.4-0.6 $\mathrm{m} \mathrm{min}^{-1}$.

These results will allow a more accurate estimation of the magnitude of the fire impact into the TMCFs ecosystems and help envisaging primary fire management policies and recommendations for the correct use of fire by the Andean indigenous communities.
\end{abstract}

Keywords: grass fires, smouldering combustion, Peruvian Andes, fire sustainability, infrared imagery. 


\section{Introduction}

Fires are one of the largest disturbances in the Neotropics leading to severe environmental impacts in terms of carbon and biodiversity losses. One of the most threatened ecosystems in this ecozone are the tropical mountain cloud forests (TMCF), that albeit they only represent about $2.5 \%$ of all tropical forests (Bubb, 2004) they harbour the highest levels of biodiversity of the world (Myers, Mittermeier, Mittermeier, da Fonseca, \& Kent, 2000).

TMCFs are mountain forests frequently covered by clouds or mist, and are usually found at altitudes between 1,500 $\mathrm{m}$ and 3,300 $\mathrm{m}$ a.s.1. (Stadmüller, 1987). Immediately above the forest, high altitude "puna" grasses are found. These grasslands have been populated for millennia by indigenous communities among which the use of fire has been a common practice for agricultural and grazing purposes as well as for supporting cultural and religious beliefs (Sarmiento \& Frolich, 2002). Despite their high moisture levels, TMCFs are increasingly suffering from drought episodes due to climate change (Román-Cuesta et al., 2011) during which anthropogenic fires starting at the puna grasslands tend to penetrate into the TMCFs causing irreversible changes to the forests structure and composition and pushing the forest-puna treeline downslope (Oliveras, Anderson, \& Malhi, 2014). Regardless of the erratic behaviour of fire in complex environments in terms of topography, fuel and wind dynamics, when a fire starts and a self-sustained flame front is formed in the puna grasslands, it usually exhibits backwards downslope flame propagation with high ratios of fuel consumption. Furthermore, under certain conditions, it can also involve smouldering propagation within the humic soil layer. Both the TMCFs and the high-altitude grasslands store large quantities of carbon. Recent studies have quantified the storage at the TMCF humic organic soil layer of $100 \mathrm{Mg} \mathrm{C} \cdot \mathrm{ha}^{-1}$ and $280 \mathrm{Mg} \mathrm{C} \cdot \mathrm{ha}^{-1}$ in the first $30 \mathrm{~cm}$ of the puna soil in the South-Eastern Peruvian Andes (Gibbon et al., 2010; Zimmermann et al., 2009), becoming then carbon losses through smouldering fires, a potentially substantial $\mathrm{CO}_{2}$ emission source.

Notwithstanding the importance of fire activity in the tropical Andes, biomass burning dynamics are still poorly understood (Oliveras et al., 2014). Firstly, little is known about the onset environmental conditions for a self-sustained flame propagation in the high-altitude grasslands. Backing fire propagation is hardly affected by wind speed but mostly influenced by fuel moisture and fuel continuity (Cheney \& Sullivan, 2008). This is particularly noteworthy in puna grasses, which are organized in discrete clumps favouring discontinuous fire behaviour. Likewise, the puna-tree line exhibits complex water dynamics among fuel and soil moisture and air relative humidity due to persistent ground-level clouds, which may result in an increased catchment water yield compared to other types of fuel (Wård, 2007). Secondly, the knowledge of the critical conditions that determine smouldering fire spread in the humic layers of the puna-tree line is very scarce. Moisture content of the carbon-rich humic layer is a key factor in controlling ignition and the subsequent spread of a smouldering front. Research in lowland rainforests has suggested a moisture content of $65 \%$ as a critical threshold for fire ignition and spread (Cochrane, 2003) but high elevation humic layers may have very different flammability characteristics, both because of the nature of the fuel and the low ambient atmospheric pressure and absolute oxygen concentration (Planas et al., 2013).

This paper presents an experimental burning program set up to advance our understanding of the critical conditions that favour fire spread in the puna-TMCFs interface. The program was performed at the south-eastern Peruvian Andes during July 2012 (mid dry season) and its objective was twofold: i) to investigate the threshold environment and fuel conditions allowing sustainable backing fire propagation in puna grasslands when advancing towards the TMCFs; and ii) to study the onset of smouldering combustion of the humic layers of the puna soil near the TMCFs treeline. The main highlights of these experiments are presented and preliminary results are summarized and briefly discussed. 


\section{Materials and methods}

\section{Experimental sites}

The study area was located at tropical Andean puna grasslands at the Cusco region (Southern Peru, bordering Manu National Park). It involved two different locations, one for the ground fire experiments $\left(13^{\circ} 10^{\prime} 50.28^{\prime}\right.$ 'S, $71^{\circ} 35^{\prime} 19.95^{\prime}$ ' W) and the other for the grassfire sustainability and behaviour tests (13 ${ }^{\circ}$ '4.26'S, $71^{\circ} 38^{\prime} 25.19^{\prime \prime} \mathrm{W}$ ) (Figure 1). This region experiences a tropical rainforest climate. Average annual rainfall ranges from 1,900 to 2,500 mm, with a wet season spanning from October to April. Mean annual temperature is approximately $11^{\circ} \mathrm{C}$ at 3,600 $\mathrm{m}$ a.s.l. (Gibbon et al., 2010). Both sites were covered by typical puna vegetation type, dominated mainly by tussock-forming grasses (Calamagrostis longearistata, Ageratina sternbergiana, Juncus bufonius, and Scirpus rigidus (Oliveras et al., submitted) with soils typically composed of an organic-rich A-layer, stony B/C-layers, and no Oh-layer (Gibbon et al., 2010; Zimmermann et al., 2009).

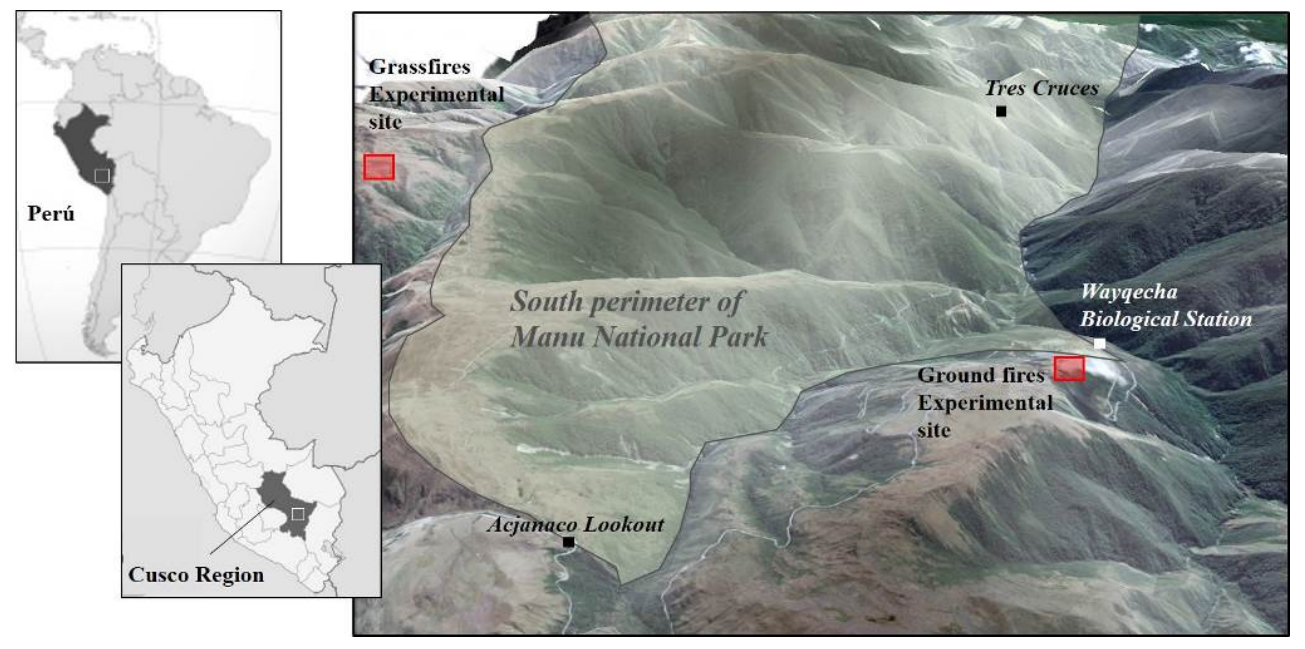

Figure 1. Study area

\section{Ground fire test experimental design}

An experimental program of smouldering fires was designed and performed in-situ. To the best of our knowledge, field burns experimentation for studying ground fires is a completely novel approach, far beyond the controlled conditions of laboratories set-ups (e.g. (Frandsen, 1998; Rein, Cleaver, Ashton, \& Pironi, 2008)) where the soil usually losses its natural compactness and state. A randomized block of 20 plots $(0.5 \mathrm{~m} \times 0.5 \mathrm{~m})$ was designed and replicated once. Five plots in every block were randomly selected as control plots (to be left unburned). Metal plates inserted $0.5 \mathrm{~m}$ deep bound all the plots (excepting the control ones), in order to avoid propagation outside the plots. The planning consisted on burning 6 plots at the same time ( 3 at every block) having then 5 sets available for five burning days. Due to meteorological constraints, only 3 sets were tested (Table 1, Figure 2).

Table 1. Random distribution of paired plots burned at each burning day (control plots in brackets)

\begin{tabular}{|l|l|l|}
\hline Date of tests start & Plots in Block W1 & Plots in Block W2 \\
\hline Day 1 & A1, B2, D1 (CP4) & B1, C1, C2 (CP4) \\
\hline Day 2 & A4, B4, B5 (CP1) & B4, D4, C5 (CP1) \\
\hline Day 3 & B1, D3, D5 (CP2) & A1, A3, A5 (CP2) \\
\hline
\end{tabular}

An ad-hoc ignition procedure was implemented, which consisted on introducing glowing charcoal in a $30 \mathrm{~cm}$ x $10 \mathrm{~cm}$ x $20 \mathrm{~cm}$ deep dug hole at one of the sides of the plot. An educated guess of the power 
supply of the ignition source was done according to data available on charcoal heat of combustion and burning rate (Shafizadeh, 1978)(Andreatta, personal communication). 98\% of the charcoal energy was assumed to be released within the first 6 hours and a mean heat transfer rate per unit area of $8,4 \mathrm{~kW} \cdot \mathrm{m}^{-}$ ${ }^{2}$ was found, being only during the first two hours above the minimum necessary for the propagation of a smouldering front, suggested at $10 \mathrm{~kW} \cdot \mathrm{m}^{-2}$ (Ohlemiller, 2002). Weather data (ambient temperature, relative humidity and wind speed and direction) was measured by a portable weather station placed between the two experimental blocks. Soil moisture content was read at $12 \mathrm{~cm}$ and 20 $\mathrm{cm}$ deep before ignition at the control plot using a Hydrosense Soil Water Measurement System (Campbell Scientific, Inc.). Grass was clipped at the experimental plots before ignition and some soil samples were extracted from the control plots and sent to the laboratory in order to obtain inorganic content and bulk density. An array of K-type metal-sheathed thermocouples of 0.5-mm diameter, 30$\mathrm{cm}$ length was used to monitor soil temperatures at two deferent depths $(5 \mathrm{~cm}$ and $15 \mathrm{~cm})$ during the tests, following Figure 3 distribution scheme. This layout was designed in order to both detect ignition (by observing the thermocouple evolution placed $5 \mathrm{~cm}$ apart from the ignition source) and pick any possible heat front propagation main direction (by observing the evolution of the rest of the sensors). The plots were left $48 \mathrm{~h}$ untouched letting the data loggers (HOBO Onset Computer Corp.) connected to the thermocouples register temperatures at a frequency of one datum per minute.

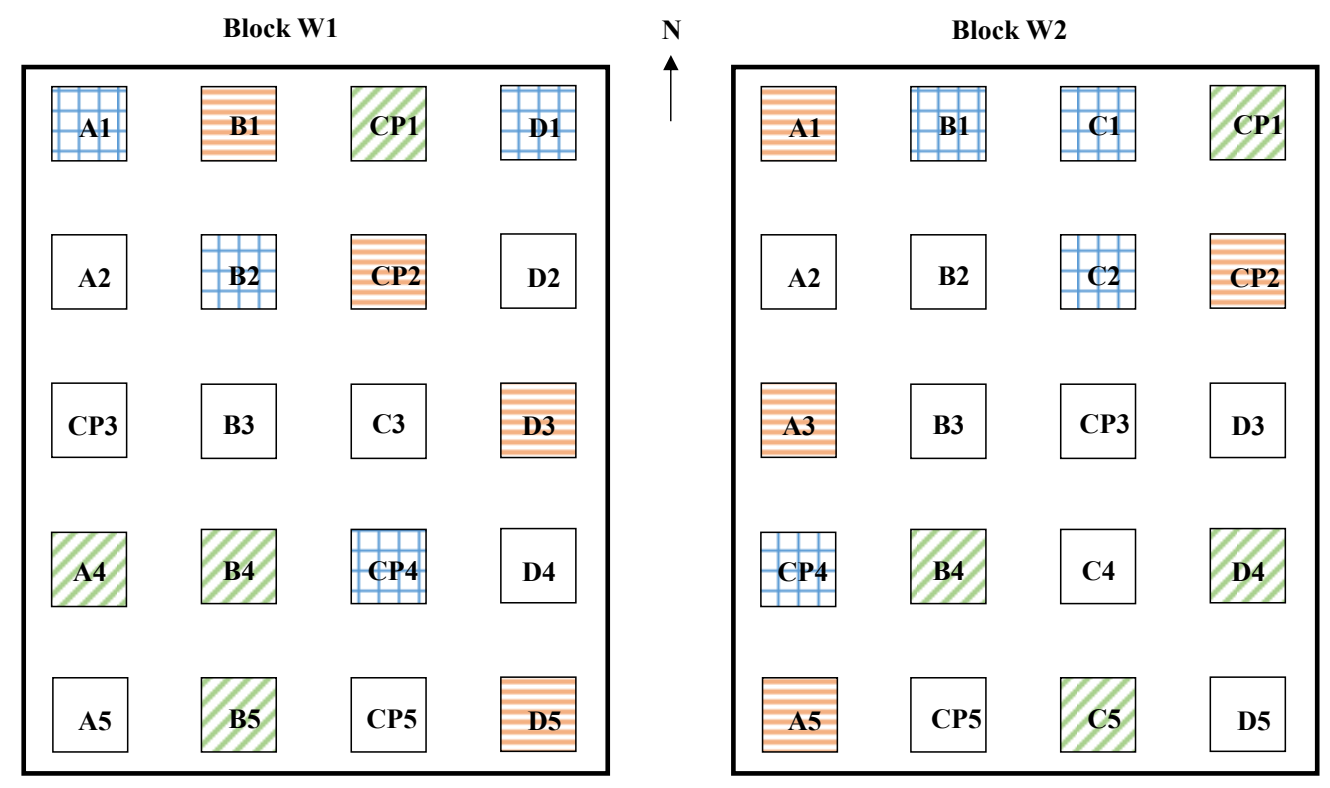

Figure 2. Plots layout at blocks W1 and W2 for ground fire experiments 


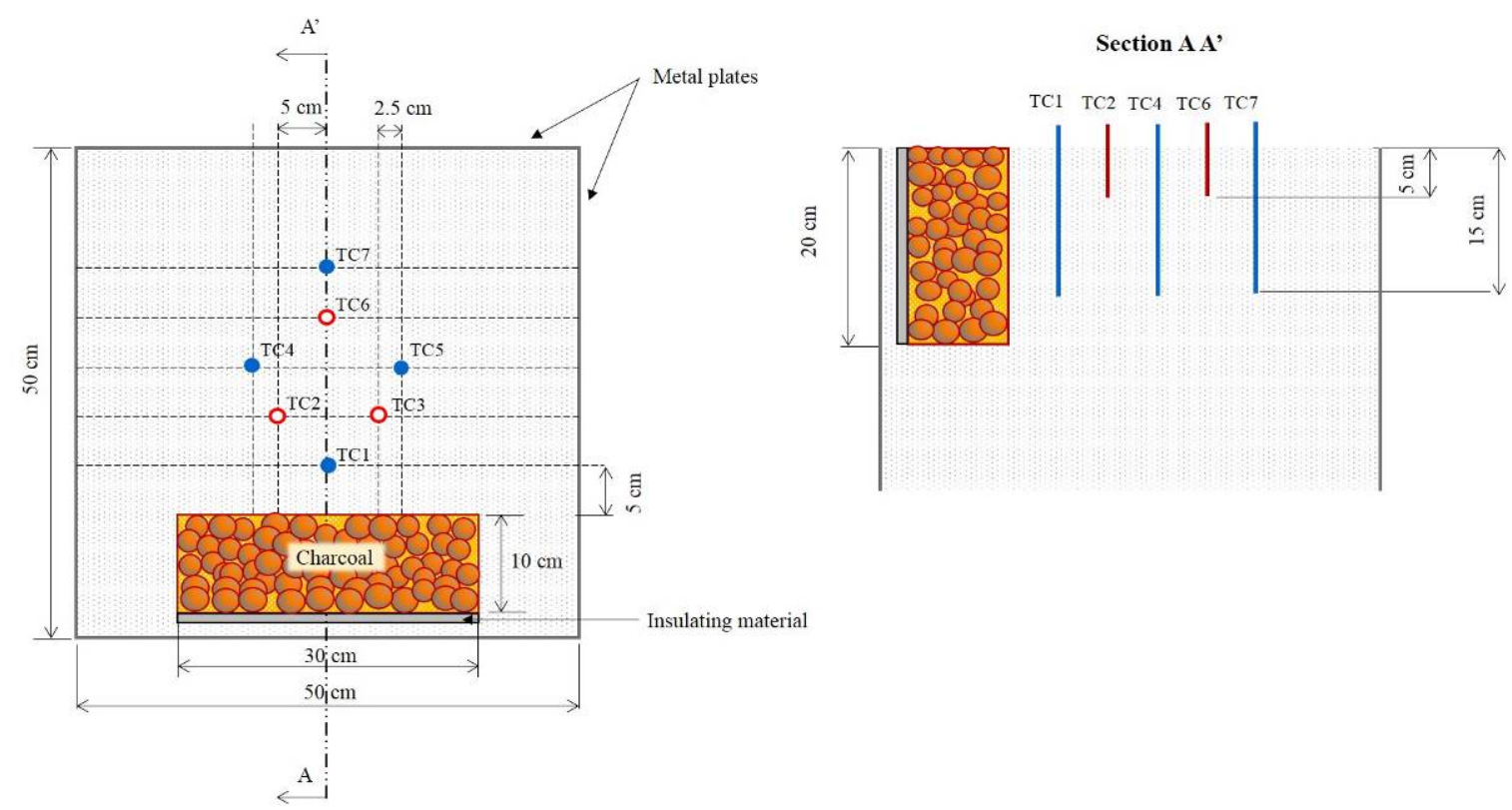

Figure 3. Thermocouples distribution used for monitoring plots temperature

\section{Grassfire sustainability and behaviour tests experimental design}

Concerning the experimental grassfires program, it covered thirteen backing fires designed to study the effect of the different weather and fuel variables in grassfire sustainability and behaviour. We stablished two $20 \mathrm{~m}$ width by $30 \mathrm{~m}$ length plots in a $40^{\circ}$ slope spot, one in 3-year old grassland (named P3) and the other in a 7-year old grass (named P7). Six experimental fires were planned in each plot, leaving $5 \mathrm{~m}$ for the fire to spread downslope. Every test was ignited with drip-torches along the leeward side of the plot. If the flame front failed to propagate, i.e. exhibited a discontinuous perimeter that tent to self-extinguish, the fire was considered a no-go, and a subsequent ignition was planned for when a significant change of meteorological conditions was observed. If the fire propagated, we would monitor its behaviour until the fire advanced $5 \mathrm{~m}$ and proceed to suppress it immediately afterwards using hand firefighting tools.

For planning purposes prior to the experiments, weather records (June-July 2011) from a local station located at $1.5 \mathrm{~km}$ from the site (Pumataki weather station) were obtained to analyse rainfall probabilities and to study relative humidity daily variation. Before the experiments, we characterized fuel loads, cover, height and degree of curing, involving a variety of sampling methods (i.e. destructive sampling and point intersect method following a systematic sampling grid within each experimental plot). During burning days, fire weather was monitored every 30 seconds, using a portable weather station located in the vicinity of the experimental plot. Fuel moisture was obtained in-situ before each burn by using an infrared-heated moisture analyser (Sartorius MA-45). Fire direct observation alongside the flame front was performed in order to have fire behaviour information. Two groups of fire observers at each plot would record flame front position, flame length and flame angle at time intervals between $30-60$ seconds.

\section{Preliminary results and discussion}

\subsection{Ground fire tests results}

Ignitions were performed in eighteen plots in three days $\left(7^{\text {th }}, 10^{\text {th }}\right.$ and $11^{\text {th }}$ July 2012) between $10: 30 \mathrm{~h}$ and 14:30h. Ambient conditions followed a similar trend at night time, with stable temperature (around $8^{\circ} \mathrm{C}$ ), relative humidity (above 90\%) and wind speed (below $2 \mathrm{~km} \cdot \mathrm{h}^{-1}$ ) for the whole experimental period. During the day, and particular at noon (from $11 \mathrm{~h}$ to $14 \mathrm{~h}$ ), weather variables had more 
fluctuations. Table 2 shows the experimental range of these environmental parameters coupling the three experimental days, together with soil properties and moisture content values at two different depths.

Table 2. Environmental parameters associated with the ground fire tests

\begin{tabular}{|l|l|}
\hline Variable & Measures \\
\hline Mean midday temperature $\left({ }^{\circ} \mathrm{C}\right)$ & $10.7-18.3$ \\
\hline Mean midday windspeed $\left(\mathrm{km} \cdot \mathrm{h}^{-1}\right)$ & $3.4-7.8$ \\
\hline Mean midday relative humidity $(\%)$ & $37.7-95.9$ \\
\hline $\begin{array}{l}\text { Soil moisture content at } 12 \mathrm{~cm}(\mathrm{SMC}, \text { d.b. } \\
\%)\end{array}$ & $90.89-130.76$ \\
\hline $\begin{array}{l}\text { Soil moisture content at } 20 \mathrm{~cm}(\mathrm{SMC}, \text { d.b. } \\
\%)\end{array}$ & $83.29-122.96$ \\
\hline Soil inorganic content $(\mathrm{IC}, \%)$ & 18 \\
\hline Soil bulk density $\left(\mathrm{BD}, \mathrm{kg} \cdot \mathrm{m}^{-3}\right)$ & 830 \\
\hline
\end{tabular}

d.b.: dry basis

Ground fire ignition is known to be controlled by soil bulk density, inorganic content and soil moisture content (Frandsen, 1997). The two first parameters were considered constants in all our study area (i.e. no differences per plot) whereas we assumed that soil moisture content could had a variation during burning days responding to meteorological changes at least at the first centimetres of soil depth. Statistical analysis was performed in order to peak possible characteristic soil moisture values per day or plot (data not shown). Significant differences were observed in soil moisture content at the two different depths but this parameter did not show any statistical significant dependence between days or blocks. This result led us to perform an aggregated analysis considering all the tests (18 in total). For all the experimental plots, we only registered noteworthy temperature response $\left(>60^{\circ} \mathrm{C}\right)$ at some thermocouples named as TC1 (5 cm apart from the ignition source, $15 \mathrm{~cm}$ depth) and at some TC2 and TC3 (both $10 \mathrm{~cm}$ apart from the ignition source, $5 \mathrm{~cm}$ depth). Table 3 summarizes the main findings obtained after processing temperature vs time evolution curves of all the active thermocouples used in our two blocks. In $67 \%$ of the cases, at least TC1 showed some significant temperature increase, achieving values above $60^{\circ} \mathrm{C}$, which is roughly the mean value corresponding to protein degradation and at which water loss starts (Cerda \& Robichaud, 2009; Swezy \& Agee, 1991). The time needed for these thermocouples to reach this threshold oscillated from $8 \mathrm{~h}$ to $16 \mathrm{~h}$ after ignition depending on the plot, which is well after the time needed for almost complete (98\%) charcoal consumption. Slightly less than half of these thermocouples reached $80^{\circ} \mathrm{C}$ (threshold for many soil microbes death, (Cerda \& Robichaud, 2009), with only 3 from 18 sensors peaking values above $100^{\circ} \mathrm{C}$ at which water vaporizes and carbon volatizes (Swezy \& Agee, 1991). We had only one case from 18 tests, at which typical ground fire front temperatures were registered (Rein et al., 2008), with a peak temperature above $400{ }^{\circ} \mathrm{C}$. Concerning TC2 and TC 3 readings, temperatures above $60^{\circ} \mathrm{C}$ were achieved in 3 cases and only in one of these, peak temperature reached $80^{\circ} \mathrm{C}$.

These results show that under our experimental conditions, there are only $6 \%$ chances for a weak ground fire ignition (i.e. a ground fire that may propagate less than $10 \mathrm{~cm}$ from the ignition point tending to self-extinguish). Furthermore, there are $17 \%$ chances for the formation of a heat front of around $60^{\circ} \mathrm{C}$ which may travel less than $15 \mathrm{~cm}$ and finally, $6 \%$ chances that the same front may reach the temperature needed for killing most of the microbes present at the soil. 
Table 3. Temperature response occurrence of the ground fire experiments.

\begin{tabular}{|l|l|l|}
\hline Peak Temperature & $\begin{array}{l}\text { Number } \\
\text { of tests }\end{array}$ & Occurrence \\
\hline TC1 at $\mathrm{T}>60{ }^{\circ} \mathrm{C}$ & $12 / 18$ & $67 \%$ \\
\hline TC1 at $\mathrm{T}>80{ }^{\circ} \mathrm{C}$ & $5 / 18$ & $28 \%$ \\
\hline $\mathrm{TC} 1$ at $\mathrm{T}>100{ }^{\circ} \mathrm{C}$ & $3 / 18$ & $17 \%$ \\
\hline $\mathrm{TC} 1$ at $\mathrm{T}>400{ }^{\circ} \mathrm{C}$ & $1 / 18$ & $6 \%$ \\
\hline TC2 $/ \mathrm{TC} 3$ at $\mathrm{T}>60{ }^{\circ} \mathrm{C}$ & $3 / 18$ & $17 \%$ \\
\hline TC2 $/ \mathrm{TC} 3$ at $\mathrm{T}>80{ }^{\circ} \mathrm{C}$ & $1 / 18$ & $6 \%$ \\
\hline
\end{tabular}

Temperature vs time profile of some selected TC1 thermocouples readings are plotted in Figure 4. TC1 of W1B1 plot is the one showing successful ignition. Soil at TC1 vicinity was 5 hours above 400 ${ }^{\circ} \mathrm{C}$, it reached a maximum temperature of $463^{\circ} \mathrm{C} 15$ hours after ignition, and it was more than 16 hours at temperatures exceeding $200^{\circ} \mathrm{C}$ (threshold for $\mathrm{N}$ volatilization (Raison, Woods, Jakobsen, \& Bary, 1986)). Considering the instant of maximum temperature as the smouldering front characteristic arrival time, we can affirm that the mean spread rate of the ground fire was $3 \mathrm{~mm} \cdot \mathrm{h}^{-1}$. This value corresponds to a self-extinguishing ground fire front and is below the typical ranges for smouldering fronts of 10$30 \mathrm{~mm} \cdot \mathrm{h}^{-1}$ (Rein, 2009).

W2A3, W1D1 and W2D4 TC1 profiles show temperature evolution of failed ignition tests. However, it is worth mentioning some interesting patterns of these three sensors: TC1 in W1D1 had a clear drop around 12 hours after ignition which would correspond to the $100 \%$ consumption of the ignition source; W2A3 TC1 had one of the longest residence time $(14 \mathrm{~h})$ above $60^{\circ} \mathrm{C}$, surpassing in this case any ignition effect. Finally, W2D4 was more than $45 \mathrm{~h}$ above this latter threshold, exhibiting plateaus at $80^{\circ} \mathrm{C}-100^{\circ} \mathrm{C}$ corresponding to the evaporation of the moisture in the soil.
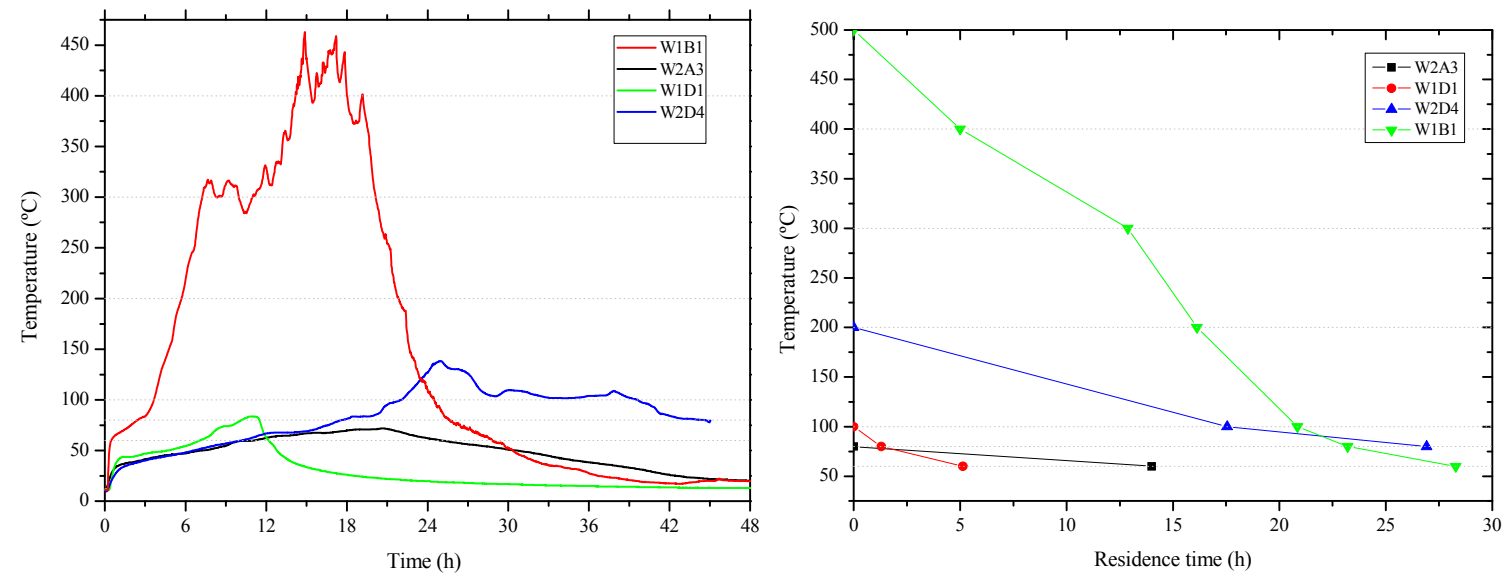

Figure 4. Left) Temperature evolution of four selected TC1 thermocouples; right) thermal severity registered by the same TC1 thermocouples

\section{Grassfires results}

The experimental program comprised a set of seven and six experimental fires in the 3-years-old puna and the 7-year-old puna, respectively performed during 4 burning days (July $5^{\text {th }}, 6^{\text {th }}, 9^{\text {th }}$ and $10^{\text {th }} 2012$ ). Figure 5 shows the evolution of the relative humidity $(\mathrm{RH})$ with time for the four days together with the exact time when the experiments were undertaken. Taking into account the expected unfavourable climatology of the area despite being at the dry season $(70 \%$ of daily raining probabilities were registered during June-July 2011 by the Pumataki weather station), a RH range of around 50 points 
could be picked during the four burning days, taking advantage of the daily fluctuation of this variable to perform several tests within the same day.

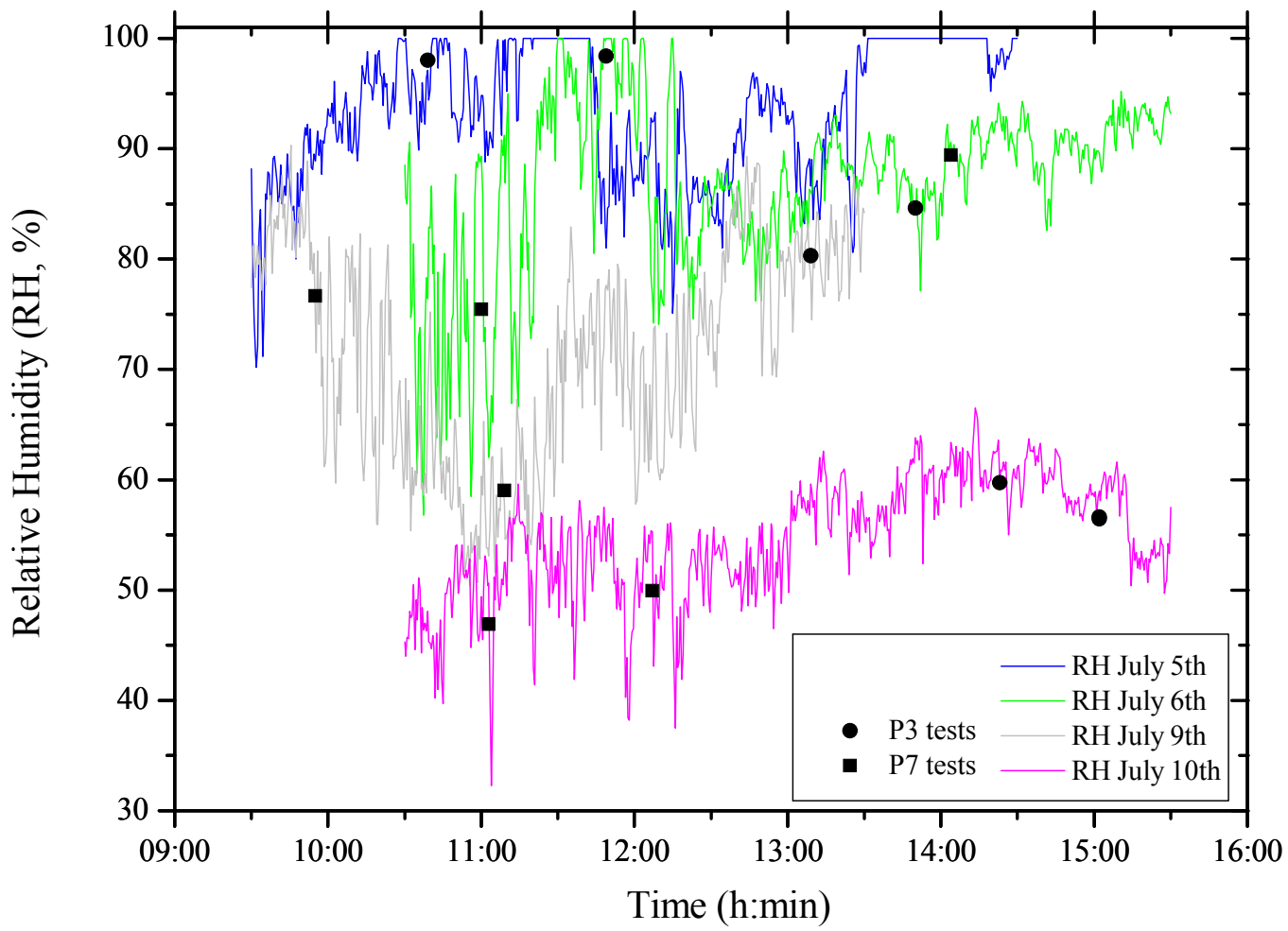

Figure 5. Relative humidity time evolution for the four burning days $\left(5^{\text {th }}, 6^{\text {th }}, 9^{\text {th }}, 10^{\text {th }}\right.$ July 2012)

Environmental parameters (i.e. fuel characteristics and fire weather) changed from one test to another. Table 4 provides the experimental range of these, partitioned by fuel type. Statistical differences between both types of fuels were explored for each variable. 3-year and 7-year old puna differed in terms of dead fuel load, degree of curing and fuel cover, whereas no statistically significant differences were found for FMC, respectively. Air temperature, RH and wind speed varied roughly within the same order of magnitude for both plots, being the latter reasonably well aligned with the slope (leeward side of the plots north/north-westerly oriented).

Table 4. Range in environmental parameters associated with the grassland fires

\begin{tabular}{|l|l|l|l|l|}
\hline Group & Variable & 3 -year puna & 7 -year puna & Statistical test $(\mathrm{p}$-value $)$ \\
\hline \multirow{5}{*}{ Fuel } & Dead fuel load $\left(\mathrm{kg} \cdot \mathrm{m}^{-2}\right)$ & $0.2-0.5$ & $0.8-1.4$ & $\begin{array}{l}\text { Mann-Whitney } \\
0.005)\end{array}$ \\
\cline { 2 - 5 } & Degree of curing $(\%)$ & $70-76$ & $78-87$ & ANOVA $(\mathrm{p}<0.005)$ \\
\cline { 2 - 5 } & Fuel cover $(\%)$ & $47.5-80$ & $75-99$ & ANOVA $(\mathrm{p}=0.005)$ \\
\cline { 2 - 5 } & $\begin{array}{l}\text { Dead fuel moisture } \\
\text { content, FMC }(\%)\end{array}$ & $8.2-30.6$ & $7.2-23.3$ & ANOVA $(\mathrm{p}=0.651)$ \\
\hline \multirow{3}{*}{$\begin{array}{l}\text { Fire } \\
\text { weather }\end{array}$} & Air temperature $\left({ }^{\circ} \mathrm{C}\right)$ & $7.8-10.6$ & $7.8-11.7$ & ANOVA $(\mathrm{p}=0.163)$ \\
\cline { 2 - 5 } & Relative humidity $(\%)$ & $57-98$ & $47-89$ & ANOVA $(\mathrm{p}=0.131)$ \\
\cline { 2 - 5 } & 2-m wind speed $\left(\mathrm{km} \cdot \mathrm{h}^{-1}\right)$ & $5.4-12.9$ & $5.8-12.6$ & ANOVA $(\mathrm{p}=0.526)$ \\
\cline { 2 - 5 } & 2-m wind direction $\left({ }^{\circ}\right)$ & $98-107$ & $80.8-98.1$ & ANOVA $(\mathrm{p}<0.005)$ \\
\hline
\end{tabular}

We counted 3 go-fires from 7 ignitions in 3-year old puna and 4 go-fires from 6 ignitions in the elder puna. We explored differences between parameters for go and no-go fires (analyzing both P3 and P7 
tests together). Figure 6 suggests fire sustainability could be explained by means of dead fuel load and dead fuel moisture content. These results are in agreement with other fire sustainability studies (Cruz \& Gould, 2010). Our preliminary results show there could be a FMC threshold between 17-23\% which could avoid fire propagation in our experimental set as well as a dead fuel load threshold around 0.2 $\mathrm{kg} \cdot \mathrm{m}^{-2}$ below which there might be not available fuel for a sustained fire spread. This idea is supported by the fact that FMC differences between go and no-go fires were found to be statistically significant (ANOVA $p=0.042$ ). However, we could not find any statistical bases related to DFL, probably because P3 mean dead fuel load is already marginal for sustained fire spread and we do not have any test with DFL significantly lower than this in our dataset.

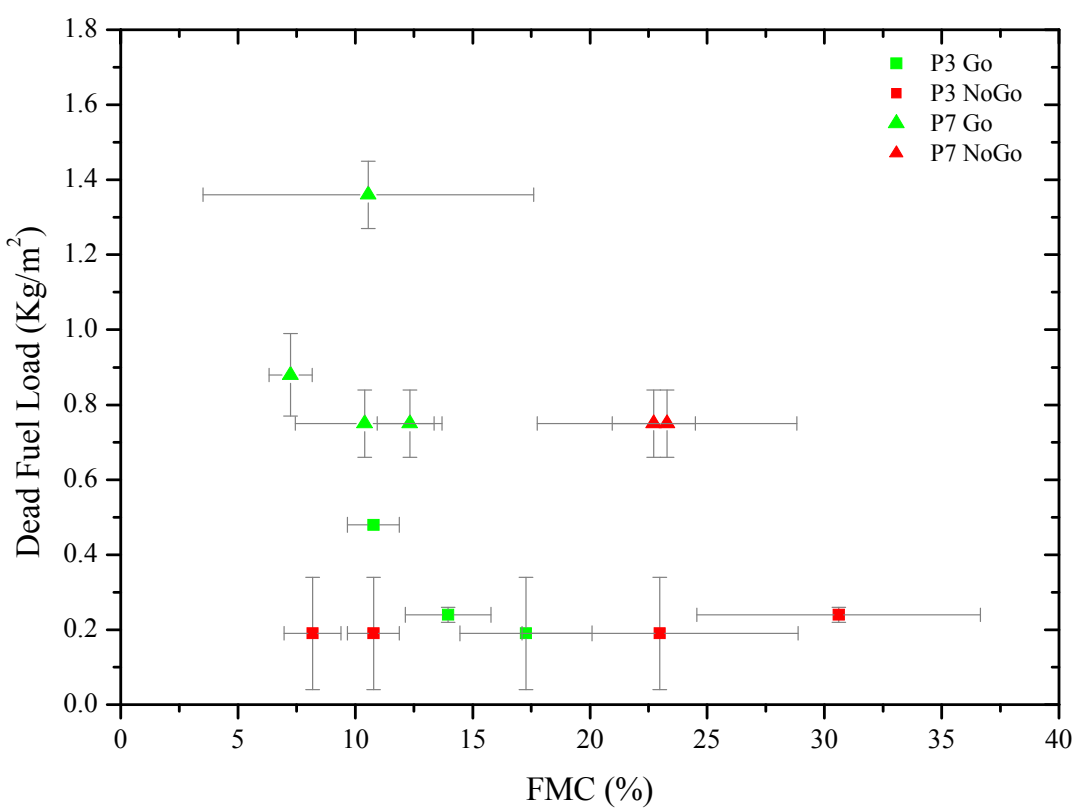

Figure 6. Go/no-Go matrix for P3 and P7 fires

Rate of spread was analysed for P3 and P7 self-sustained fires. There was a convergence to a pseudostationary rate of spread for all P3 (a) and all P7 (c) go-fires (Figure 7). Analysing ROS averages at 2minutes intervals, it can be observed how steady state was achieved after 10 minutes in P3 fires with a mean stationary propagation of $0.37 \mathrm{~m} / \mathrm{min}$ (s.d. 0.038), and after 8 minutes in P7 fires, at $0.56 \mathrm{~m} / \mathrm{min}$ (s.d. 0.095). A 2-Sample t-test between all P3 ROS observations and all P7 ones, denoted dissimilarity between groups $(\mathrm{p}<0.005)$. This difference can be explained in terms of relative humidity (ANOVA $\mathrm{p}=0.02$ ), curing degree (ANOVA $\mathrm{p}=0.013$ ) and dead fuel load (ANOVA $\mathrm{p}=0.02$ ). The latter result highlights the important role of the amount of available fuel on fire behaviour in this type of ecosystem. 


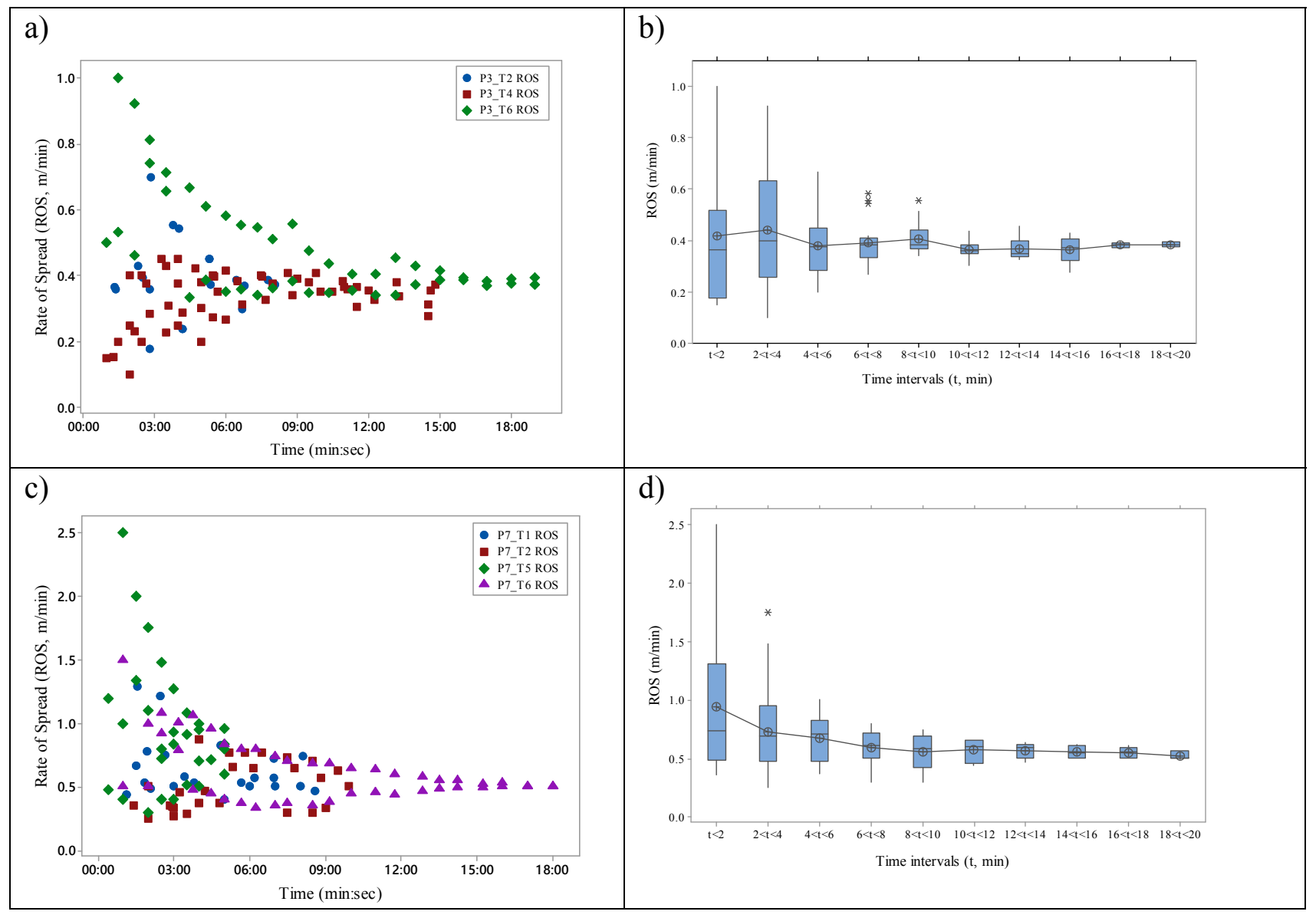

Figure 7. ROS evolution for P3 tests and P7 tests; left) Scatterplots of all fire observations sorted by tests at a) P3 and c) P7; right) evolution of 2-min interval mean ROS value for all b) P3 and d) P7 dataset.

Byram's fireline intensity, flame length of the leading edge and flame angle (defined as the inclination of the leading edge from the vertical) are presented in Table 5. According to these, experimental tests are in agreement with low intensity back-fire regime figures (Andrews, Heinsch, \& Schelvan, 2011). The lowest mean fire intensity computed corresponds to test 6 of 3 -year puna, and equals to 18.9 $\mathrm{kW} \cdot \mathrm{m}^{-1}$ (s.d. 4.5) which can be considered the threshold for backfire spread by flaming combustion in the study area. It is to be highlighted that this threshold almost doubles the headfire spread minimum intensity limit set at $10 \mathrm{~kW} \cdot \mathrm{m}^{-1}$ (Alexander, 2000) which reveals the existing differences between head and backfire propagation mechanisms.

Table 5. Mean values of fireline intensity and flame geometry characteristics

\begin{tabular}{|l|l|l|l|}
\hline & $\begin{array}{l}\text { Fireline Intensity }\left(\mathrm{kW} \cdot \mathrm{m}^{-}\right. \\
\left.{ }^{1}\right)\end{array}$ & Flame angle $\left(^{\circ}\right)$ & Flame length (m) \\
\hline P3 & $39.5($ s.d. 27.6) & $45.8^{\circ}$ (s.d. 12.9) & 0.34 (s.d. 0.23) \\
\hline P7 & 180.1 (s.d. 82.9) & $46.0^{\circ}$ (s.d.13.6) & 0.94 (s.d. 0.57) \\
\hline
\end{tabular}

\section{Concluding remarks}

A twofold experimental program was performed to study critical conditions that favour fire spread in the puna-TMCFs interface, providing understanding of the threshold environment and fuel conditions allowing sustainable ground smouldering fires and back-propagation grassfires. These results will 
allow a more accurate estimation of the magnitude of the fire impact into the TMCFs ecosystems and will help envisaging primary fire management policies.

A novel methodology for in-situ ground fire tests has been developed and found successful, being our experimental dataset the first of these characteristics, far beyond the controlled conditions of laboratories set-ups. Conditions tested have been found marginal for self-sustained propagation (SMC between $91-131 \%$, IC $18 \%$ and BD $830 \mathrm{~kg} \cdot \mathrm{m}^{-3}$ ). However, in one particular case, a smouldering front has been observed advancing $5 \mathrm{~cm}$ in $15 \mathrm{~h}$, with typical temperature ranges above $400^{\circ} \mathrm{C}$. In $67 \%$ of the tests, temperatures for biological molecules denaturation have been reached with residence times up to $14 \mathrm{~h}$ but the water evaporation threshold has been only surpassed in 3 tests, which confirms that given the physical properties of the soil, moisture content has been the factor preventing self-sustained smouldering fires in our dataset. Despite the front propagation has been in all plots weaker than in many of the lab-scale tests reported in the literature, residence times found in our experimentation are substantially larger and not dependent on the ignition source used.

Sustainability of back fires at the puna grasses sitting above the TMCFs is a key aspect when studying fire occurrence and its environmental implications at the forest-puna treeline. A complete understanding of this phenomenon is needed for fire managing purposes, in particular for debriefing indigenous communities about the correct use of fire. Our grassfire behaviour and sustainability experiments have proved that fire sustainability at the Andean puna can be explained by key fuel parameters. Fuel moisture content has a preponderant role and dead fuel load appears to be also important. For dry season, we suggest initial thresholds of $20 \%$ and $0.2 \mathrm{~kg} \cdot \mathrm{m}^{-2}$, respectively, to be used in our study area. However, our dataset would have to be enlarged with more experimental campaigns to precise these figures. Due to the difficulty and cost of this type of experimentation, physical or quasi-physical simulation appears to be the most feasible alternative to burning campaigns. With a complete experimental design, a simulation-based probabilistic model for fire sustainability could be obtained, which should be of great help for management purposes in the zone of influence of our study area and in other Andean emerging fire-prone grasslands, provided the selected fire simulation tool is validated with the already available experimental dataset.

Steady state fire spread at puna of different ages has been achieved in the go-fires of our experimental campaign. Relative humidity, curing degree and dead fuel load are the key parameters that have major influence on the rate of spread in our experimental dataset. The limit for sustained back-fire spread has been found at around $20 \mathrm{~kW} \cdot \mathrm{m}^{-1}$. This is the minimum power needed for the flame front to overcome grass clumps discontinuities. Rate of spread, fireline intensity and flame dimensions have been accurately quantified for 3-year and 7-year puna grasses. These are the main variables arisen from the heat transfer processes between the fireline and the surrounding environment. This information can be of great help when evaluating different aspects of fire impact and the ecosystem response to it. In particular, this data with such a degree of accuracy shall be useful to improve carbon losses estimations.

\section{Acknowledgements}

This research was funded by the Spanish Ministerio de Economia y Competitividad under the project AGL2011-23425. The authors also thank the Autonomous Government of Catalonia for financial support (project No. 2009SGR1118). Support has also been received from Asociación para la Conservación de la Cuenca Amazónica (ACCA) and Parque Nacional del Manu-INRAENA.

\section{References}

Acem, Z., Lamorlette, A., Collin, A., \& Boulet, P. (2009). Analytical determination and numerical computation of extinction coefficients for vegetation with given leaf distribution. International Journal of Thermal Sciences, 48 , 1501-1509. 
Alexander, M. E. (2000). Fire behaviour as a factor in forest and rural fire suppression (p. 30). Forest Research; Forest and Rural Fire Scientific and Technical Ser; Rotorua; Wellington. Forest Research Bulletin No. 197; in association with the National Rural Fire Author.

Amorim, J. H. (2011a). Numerical modelling of the aerial drop of firefighting agents by fixed-wing aircraft. Part I: model development. International Journal of Wildland Fire, 20(3), 384-393.

Amorim, J. H. (2011b). Numerical modelling of the aerial drop of firefighting agents by fixed-wing aircraft. Part II: model validation. International Journal of Wildland Fire. doi:10.1071/WF09123

Amorim, J. H., Miranda, A. I., Valente, J., Borrego, C., Viegas, D. X., Pita, L. P., \& Ribeiro, L. M. (2010). Effects of chemical retardants on air pollutants emissions: measurements in a combustion chamberNo Title. In D. X. Viegas (Ed.), VI International Conference on Forest Fire Research (ICFFR) (p. 267). Coimbra: University of Coimbra.

Andrews, P. L., Heinsch, F. A., \& Schelvan, L. (2011). How to generate and interpret fire characteristics charts for surface and crown fire behavior (p. 48). Gerenal Technical Report RMRS-GTR-253.

Boulet, P. (n.d.). Personal communication 26/02/2014.

Boulet, P., Parent, G., Acem, Z., Collin, A., Försth, M., Bal, N., ... Torero, J. (2014). Radiation emission from a heating coil or a halogen lamp on a semitransparent sample. International Journal of Thermal Sciences, 77, 223-232.

Bubb, P. (2004). Cloud forest agenda (p. 36). Cambridge, UK.: UNEP-WCMC.

Carvalho, A., Flannigan, M. D., Logan, K. A., Gowman, L. M., Miranda, A. I., \& Borrego, C. (2010). The impact of spatial resolution on area burned and fire occurrence projections in Portugal under climate change. Climatic Change, 98, 177-197. doi:10.1007/s10584-009-9667-2

Carvalho, A., Flannigan, M. D., Logan, K., Miranda, A. I., \& Borrego, C. (2008). Fire activity in Portugal and its relationship to weather and the Canadian Fire Weather Index System. International Journal of Wildland Fire. doi:10.1071/WF07014

Carvalho, A., Monteiro, A., Flannigan, M., Solman, S., Miranda, A. I., \& Borrego, C. (2011). Forest fires in a changing climate and their impacts on air quality. Atmospheric Environment, 45, 55455553. doi:10.1016/j.atmosenv.2011.05.010

Cerda, A., \& Robichaud, P. R. (2009). Fire Effects on Soils and Restoration Strategies (p. 605). CRC Press.

Cheney, P., \& Sullivan, A. (2008). Grassfires: fuel, weather and fire behaviour. (p. 150). CSIRO Publishing.

Cochrane, M. A. (2003). Fire science for rainforests. Nature, 421(6926), 913-9. doi: $10.1038 /$ nature 01437

Consalvi, J. L., Nmira, F., Fuentes, A., Mindykowski, P., \& Porterie, B. (2011). Numerical study of piloted ignition of forest fuel layer. Proceedings of the Combustion Institute, 33 , 2641-2648.

Cruz, M. G., \& Gould, J. S. (2010). Fuel and fire behaviour in semi-arid mallee-heath shrublands. In D. X. Viegas (Ed.), 6th International Forest Fire Research Conference. Coimbra, Portugal: ADAI.

De Mestre, N. J., Catchpole, E. A., Anderson, D. H., \& Rothermel, R. C. (1989). Uniform Propagation of a Planar Fire Front without Wind. Combustion Science and Technology, 65(4-6), 231-244.

Frandsen, W. (1997). Ignition probability of organic soils. Canadian Journal of Forest Research, 27(9), 1471-1477. doi:10.1139/x97-106

Frandsen, W. (1998). Heat Flow Measurements From Smoldering Porous Fuel. International Journal of Wildland Fire, 8(3), 137. doi:10.1071/WF9980137

Fureby, C., Tabor, G., Weller, G., \& Gosman, D. (1997). A comparative study of subgrid scale models in homogeneous isotropic turbulence. Physics of Fluids, 9(5) , 1416-1429.

Gibbon, A., Silman, M. R., Malhi, Y., Fisher, J. B., Meir, P., Zimmermann, M., ... Garcia, K. C. (2010). Ecosystem Carbon Storage Across the Grassland-Forest Transition in the High Andes of Manu National Park, Peru. Ecosystems, 13(7), 1097-1111. 
Grishin, A. M., \& Albini, F. (1997). A Mathematical Modelling of Forest Fires and New Methods of Fighting Them. Publishing House of the Tomsk University, Tomsk, Russia .

Incropera, F. P., DeWitt, D. P., Bergman, T. L., \& Lavine, A. S. (2007). Fundamentals of Heat and Mass Transfer. (F. P. Incropera \& F. P. F. O. H. A. M. T. Incropera, Eds.)Water (Vol. 6th, p. 997). John Wiley \& Sons. doi:10.1016/j.applthermaleng.2011.03.022

Jain, A. K. (2007). Global estimation of CO emissions using three sets of satellite data for burned area. Atmospheric Environment, 41, 6931-6940. doi:10.1016/j.atmosenv.2006.10.021

Lamorlette, A., \& Collin, A. (2012). Analytical quantification of convective heat transfer inside vegetal structures. International Journal of Thermal Sciences, 57 , 78-84.

Larini, M., Giroud, F., Porterie, B., \& Loraud, J. C. (1998). A multiphase formulation for fire propagation in heterogeneous combustible media. International Journal of Heat and Mass Transfer, 41(6-7), 881-897.

Lesieur, M. (2008). Turbulence in fluids. (R. MOREAU, Ed.) (fourth.). Springer.

Long, R., Torero, J., Quintiere, J., \& Fernandez-Pello, A. (1999). Scale and transport considerations on piloted ignition of PMMA. In Fire Safety Science - Proceedings of the sixth International Symposium (pp. 567-578).

Marcos Chaos. (2014). Spectral Aspects of Bench-Scale Flammability Testing: Application to Hardwood Pyrolysis. In Fire Safety Science-Draft Proceedings of the Eleventh International Symposium.

Margerit, J., \& Sero-Guillaume, O. (2002). Modelling forest fires. Part II: Reduction to twodimensional models and simulation of propagation. International Journal of Heat and Mass Transfer, 45, 1723-1737. doi:10.1016/S0017-9310(01)00249-6

Martins, V., Miranda, A. I., Carvalho, A., Schaap, M., Borrego, C., \& Sá, E. (2012). Impact of forest fires on particulate matter and ozone levels during the 2003, 2004 and 2005 fire seasons in portugal. Science of the Total Environment, 414, 53-62. doi:10.1016/j.scitotenv.2011.10.007

Mcallister, S., Grenfell, I., Hadlow, A., Jolly, W. M., Finney, M., \& Cohen, J. (2012). Piloted ignition of live forest fuels. Fire Safety Journal, 51, 133-142. doi:10.1016/j.firesaf.2012.04.001

Mell, W., Jenkins, M. A., Gould, J., \& Cheney, P. (2007). A physics-based approach to modelling grassland fires. International Journal of Wildland Fire, 16(1), 1-22.

Mell, W., Maranghides, A., McDermott, R., \& Manzello, S. L. (2009). Numerical simulation and experiments of burning douglas fir trees. Combustion and Flame, 156 , 2023-2041.

Miranda, A. ., Sá, E., Martins, V., Borrego, C., \& Sofiev, M. (2010). The Russian spring 2006 wildland fires effects on air quality over Europe. In D. X. Viegas (Ed.), 6th International Conference on Forest Fire Research (p. 8). Coimbra: University of Coimbra.

Miranda, A. I. (2004). An integrated numerical system to estimate air quality effects of forest fires. International Journal of Wildland Fire, 13, 217-226. doi:10.1071/WF02047

Miranda, A. I., Borrego, C., Martins, H., Martins, V., Jorge, H., Valente, J., \& Carvalho, A. (2009). Earth Observation of Wildland Fires in Mediterranean Ecosystems. Earth, 171-187. doi:10.1007/978-3-642-01754-4

Miranda, A. I., Coutinho, M., \& Borrego, C. (1994). Forest fire emissions in Portugal: A contribution to global warming? In Environmental Pollution (Vol. 83, pp. 121-123). doi:10.1016/02697491(94)90029-9

Miranda, A. I., Marchi, E., Ferretti, M., \& Millán, M. (2009). Chapter 9 Forest Fires and Air Quality Issues in Southern Europe. In M. J. A. Andrzej Bytnerowicz Allen R. Riebau and Christian Andersen BT - Developments in Environmental Science (Ed.), Wildland Fires and Air Pollution (Vol. Volume 8, pp. 209-231). Elsevier. doi:http://dx.doi.org/10.1016/S1474-8177(08)00009-0

Miranda, A. I., Martins, V., Cascão, P., Amorim, J. H., Valente, J., Borrego, C., ... Ottmar, R. (2012). Wildland smoke exposure values and exhaled breath indicators in firefighters. Journal of Toxicology and Environmental Health. Part A, 75(13-15), 831-43. doi:10.1080/15287394.2012.690686 
Miranda, A. I., Martins, V., Cascão, P., Amorim, J. H., Valente, J., Tavares, R., ... Pita, L. P. (2010). Monitoring fire-fighters' smoke exposure and related health effects during Gestosa experimental fires (Vol. 137, pp. 83-94). doi:10.2495/FIVA100081

Miranda, AI, Ferreira, J, \& Valente. (2005). Smoke measurements during Gestosa-2002 experimental field fires, 14(1), 107-116. doi:10.1071/WF04069

Monod, B., Collin, A., Parent, G., \& Boulet, P. (2009). Infrared radiative properties of vegetation involved in forest fires. Fire Safety Journal, 44 , 88-95.

Monteiro, A., Corti, P., San Miguel-Ayanz, J., Miranda, A. I., \& Borrego, C. (2014). The EFFIS forest fire atmospheric emission model: Application to a major fire event in Portugal. Atmospheric Environment, 84, 355-362. doi:10.1016/j.atmosenv.2013.11.059

Monteiro, A., Miranda, A. I., Borrego, C., Vautard, R., Ferreira, J., \& Perez, A. T. (2007). Long-term assessment of particulate matter using CHIMERE model. Atmospheric Environment, 41, 77267738.

Morvan, D., \& Dupuy, J. L. (2001). Modelling of fire spread trough a forest fuel bed using a multiphase formulation. Combustion and Flame, 124 , 1981-1994.

Morvan, D., Dupuy, J. L., Rigolot, E., \& Valette, J. C. (2006). FIRESTAR: a physically based model to study wildfire behaviour. Forest Ecology and Management, 234S, S114.

Morvan, D., Mèradji, S., \& Accary, G. (2009). Physical modelling of fire spread in Grasslands. Fire Safety Journal, 44(1), 50-61.

Myers, N., Mittermeier, R. A., Mittermeier, C. G., da Fonseca, G. A., \& Kent, J. (2000). Biodiversity hotspots for conservation priorities. Nature, 403(6772), 853-8. doi:10.1038/35002501

Nepf, H. M., Sullivan, J. A., \& Zavitoski, R. A. (1997). A model for diffusion within an emergent plant canopy. Limnology and Oceanography, 42(8), 85-95.

Ohlemiller, T. J. (2002). Smoldering Combustion. In P. J. DiNenno, D. Drysdale, C. L. Beyler, \& W. D. Walton (Eds.), SFPE Handbook of Fire Protection Engineering (3rd ed., pp. 200-210). NFPA.

Oliveras, I., Anderson, L. O., \& Malhi, Y. (2014). Application of remote sensing to understanding fire regimes and biomass burning emissions of the tropical Andes. Global Biogeochemical Cycles, 28, 480-496. doi:10.1002/2013GB004664

Oliveras, I., C., D., Cahuana, N., C., E. A., W., H., \& Malhi, Y. (n.d.). Andean grasslands are as productive as tropical montane cloud forests. Environmental Research Letters.

OpenFOAM User Guide, OpenFOAM The Open Source CFD Toolbox . (2010).

Ottmar, R. D., Miranda, A. I., \& Sandberg, D. V. (2008). Chapter 3 Characterizing Sources of Emissions from Wildland Fires. Developments in Environmental Science. doi:10.1016/S14748177(08)00003-X

Ottmar, R. D., Sandberg, D. V, Riccardi, C. L., \& Prichard, S. J. (2007). An overview of the Fuel Characteristic Classification System - Quantifying, classifying, and creating fuelbeds for resource planningThis article is one of a selection of papers published in the Special Forum on the Fuel Characteristic Classification Syste. Canadian Journal of Forest Research, 37(12), 2383-2393. doi:10.1139/X07-077

Planas, E., Oliveras, I., Manta, M. I., Urquiaga, E., Quintano, J. A., \& Pastor, E. (2013). Soil combustion experiments in the Andean grassland (puna) and tropical montane cloud forests (TMCFs) treeline. In Fourth Fire Behaviour and Fuels Conference (p. 51). Saint Petersburg, Russia.

Raison, R., Woods, P., Jakobsen, B., \& Bary, G. (1986). Soil temperatures during and following lowintensity prescribed burning in a Eucalyptus pauciflora forest. Australian Journal of Soil Research, 24(1), 33. doi:10.1071/SR9860033

Raupach, M. R., \& Thom, A. S. (1981). Turbulence in and above plant canopies. Annual Review of Fluid Mechanics, 13 , 97-129.

Reh, C. M., Letts, D., \& Deitchman, S. (1994). Health hazard evaluation report. California. 
Rein, G. (2009). Smouldering Combustion Phenomena in Science and Technology. International Review of Chemical Engineering, 1, 3-18.

Rein, G., Cleaver, N., Ashton, C., \& Pironi, P. (2008). The severity of smouldering peat fires and damage to the forest soil. Catena, 74(3), 304-309.

Ren, N., Wang, Y., \& Trouvé, A. (2013). Large Eddy Simulation of Vertical Turbulent Wall Fires. Procedia Engineering, 62, 443-452. doi:10.1016/j.proeng.2013.08.086

Román-Cuesta, R. M., Salinas, N., Asbjornsen, H., Oliveras, I., Huaman, V., Gutiérrez, Y., ... Malhi, Y. (2011). Implications of fires on carbon budgets in Andean cloud montane forest: The importance of peat soils and tree resprouting. Forest Ecology and Management, 261(11), 1987-1997.

Safi, M. J., Mishra, I. M., \& Prasad, B. (2004). Global degradation kinetics of pine needles in air. Thermochimica Acta, 412(1-2), 155-162. doi:10.1016/j.tca.2003.09.017

San-Miguel-Ayanz, J., Schulte, E., Schmuck, G., \& Camia, A. (2013). The European Forest Fire Information System in the context of environmental policies of the European Union. Forest Policy and Economics, 29, 19-25. doi:10.1016/j.forpol.2011.08.012

San-Miguel-Ayanz, J. Steinbrecher, R. (2009). EMEP-EEA emissions inventory guidebook (p. 19). Copenhagen.

Sarmiento, F. O., \& Frolich, L. M. (2002). Andean Cloud Forest Tree Lines. Naturalness, Agriculture and the Human Dimension. Mountain Research and Development, 22(3), 278-287. doi:10.1659/0276-4741

Schemel, C. F., Simeoni, A., Biteau, H., Rivera, J. D., \& Torero, J. L. (2008). A calorimetric study of wildland fuels. Experimental Thermal and Fluid Science, 32(7), 1381-1389.

Séro-Guillaume, O., \& Margerit, J. (2002). Modelling forest fires. Part I: a complete set of equations derived by extended irreversible thermodynamics. Int. J.Heat Mass Transfer, 45 , 1705-1722.

Shafizadeh, F. (1978). Combustion, combustibility, and heat release of forest fuels. AIChE Symposium Series, 74:177.

Shaw, R. H., \& Patton, E. G. (2003). Canopy element influences on resolved- and sub-grid-scale energy within a large-eddy simulation. Agricultural and Forest Meteorology, 115 , 5-17.

Siegel, R., \& Howell, J. R. (1992). Thermal Radiation Heat Transfer (Vol. third ed. ). Hemisphere Publishing Corportation .

Simeoni, A., Thomas, J. C., Bartoli, P., Borowieck, P., Reszka, P., Colella, F., ... Torero, J. L. (2012). Flammability studies for wildland and wildland-urban interface fires applied to pine needles and solid polymers. Fire Safety Journal, 54(0), 203-217.

Stadmüller, T. (1987). Cloud Forests in the Humid Tropics: A Bibliographic Review. United Nations University Press.

Stroppiana, D., Grégoire, J.-M., \& Pereira, J. M. C. (2003). The use of SPOT VEGETATION data in a classification tree approach for burnt area mapping in Australian savanna. International Journal of Remote Sensing, 24(10), 2131-2151. doi:10.1080/01431160210154911

Swezy, D. M., \& Agee, J. K. (1991). Prescribed-fire effects on fine-root and tree mortality in oldgrowth ponderosa pine. Canadian Journal of Forest Research, 21(5), 626-634.

Tamura, H., Kiya, M., \& Arie, M. (1980). Vortex shedding from a circular cylinder in moderateReynlods-number shear flow. Journal of Fluid Mechanics, 141 , 721-735.

Thomas Simeoni A. Colella F. Torero J.L., J. C. (2011). Piloted Ignition Regimes of Wildland Fuel Beds.

Thomas, J. C., Everett, J. N., Simeoni, A., Skowronski, N., \& Torero, J. L. (2013). Flammability Study of Pine Needle Beds. In Proc. of the Seventh International Seminar on Fire \& Explosion Hazards (ISFEH7). doi:10.3850/978-981-08-7724-8

Valente, J., Miranda, A. I., Lopes, A. G., Borrego, C., Viegas, D. X., \& Lopes, M. (2007). Local-scale modelling system to simulate smoke dispersion. International Journal of Wildland Fire, 16(2), 196. doi:10.1071/WF06085 
Van Der Werf, G. R., Randerson, J. T., Giglio, L., Collatz, G. J., Mu, M., Kasibhatla, P. S., ... Van Leeuwen, T. T. (2010). Global fire emissions and the contribution of deforestation, savanna, forest, agricultural, and peat fires (1997-2009). Atmospheric Chemistry and Physics, 10, 11707-11735. doi:10.5194/acp-10-11707-2010

Wård, Y. (2007). Tropical Montane Cloud Forest- Fire Disturbance and Water Input after Disturbance (pp. 1-28). Umeå: Swedish University of Agricultural Sciences.

Williamson, C. H. K. (1992). The natural and forced formation of spot-like "vortex dislocations" in the transition of a wake. Journal of Fluid Mechanics, 243 , 393-441.

Zimmermann, M., Meir, P., Silman, M. R., Fedders, A., Gibbon, A., Malhi, Y., ... Zamora, F. (2009). No Differences in Soil Carbon Stocks Across the Tree Line in the Peruvian Andes. Ecosystems, 13(1), 62-74. doi:10.1007/s10021-009-9300-2 